\title{
EXCLUSIVE RIGHTS CLAUSES IN SHOPPING CENTRE LEASES*
}

\author{
ALAN SCHAPIRO**
}

\section{INTRODUCTION}

Developers of shopping centres strive to create the ideal mix of stores to attract customer traffic, while at the same time protecting tenants against undue competition, otherwise the entire shopping centre may suffer. A successful shopping centre contains a mix of stores which is beneficial to all of the tenants. A small shopping centre in a suburban residential area, for example, can only be successful and is usually planned on the basis of a tenant mix that is not unduly competitive. Since there is a limited source of customer traffic from the neighborhood resulting in a limited amount of business being transacted at the shopping centre, the tenants rely that a prospective customer shopping in one store will turn to another store in the same shopping centre to purchase another kind of goods or service being offered by such other store. If the limited number of prospective purchasers are faced with a number of similar shops in the same shopping centre, there may not be sufficient business to support the tenants carrying on the same type of business and as a consequence both the tenants and the landlord will suffer. Accordingly, to create a community of interest the operator of the shopping centre will strive to assure tenants of a reasonable degree of competition yet provide protection through an orderly scheme of development.

Often, a tenant will seek to obtain a covenant from the landlord that grants the tenant the exclusive right to conduct the tenant's type of business or sell a specified line of merchandise in the shopping centre. Such covenants may also prohibit the landlord from leasing space in the shopping centre to a competing store, or otherwise limit competition in certain lines of merchandise sold by a competing tenant in the same shopping centre. Such clauses, prohibiting the landlord's rights to lease premises in favour of a particular tenant, when expressed positively, are referred to as "exclusives" and "exclusive rights clauses", or "restrictive covenants" when expressed in the negative.'

Lord Justice Fry in Stuart v. Diplock Bros. clearly stated that restrictive covenants are not to be stretched beyond the ordinary meaning of the words and held that: ${ }^{2}$

The sale by a hosier in the ordinary course of his business of certain articles sold by a ladies' outfitter, is not a breach of a covenant not to carry on the business of ladies' outfitter, even if the articles sold form a substantial part of the business of a ladies' outfitter.

In the Stuart case, the plaintiff sought to protect the business of ladies' outfitting and the defendant operated a hosiery business in which he sold

* This article was prepared for and presented at the International Council of Shopping Centers' Canadian Law Conference, Toronto, September 1985. The author also wishes to acknowledge Ms. Kim Mathias who assisted in the research for the article.

* Partner in firm of Witten Binder, Edmonton, Alberta.

1. Cf. Harvey M. Haber and Stephen J. Messinger, "Exclusive Rights and Non-Competitive Clauses", Shopping Centre Leases (Harvey M. Haber ed. 1976).

2. (1889) 59 L.J. Ch. 142 at 145. 
four classes of articles, the sale of which was part of the business of the ladies' outfitter.

In $K \& L$ Higgins Ltd. v. Yonge-Eglinton Building Ltd. ${ }^{3}$ the question to be decided was whether the defendant landlord was in breach of an exclusive rights clause in the lease entered into by the parties. The leased premises were to be used only for the purposes of an "office supply stationery store". The terms of the lease further permitted the plaintiff to sell supplies other than office supplies and, after listing several specific items, concluded with the words "and all items normally associated with a stationery, smoke and gift store"'. The defendant landlord covenanted not to rent premises in the building to any other tenant "for the purpose of carrying on a business similar in any way to that of the tenant ...." Subsequently, the defendant landlord leased premises in the shopping concourse of the building to a tenant operating a "Supersave Drug Mart" store, which by the terms of its lease, was entitled to carry on the business of "a retail drug store and pharmacy for the sale of prescription drugs, patent medicines, health and beauty aids, tobacco products and other sundry merchandise as is generally dealt in by the tenant". The "Supersave Drug Mart" lease further provided that "the tenant will not ... sell goods normally associated with an office supply and stationery supply store ...."

The plaintiff argued that "Supersave Drug Mart" operated a business similar to that of the plaintiff, inasmuch as $35 \%$ of its business competed in the tobacco, magazine and other areas which the plaintiff argued it had the exclusive right to sell. The plaintiff cautioned the defendant landlord that there was a breach of the restrictive covenant and after this was denied by the landlord, the plaintiff brought an injunction restraining the defendant landlord and "Supersave Drug Mart" from violating the restrictive covenant in the plaintiff's lease.

In delivering judgment, Lacourciere $J$. held that the action should be dismissed. The crux of the case was the characterization of the plaintiff's business. The intention of the parties was to be determined by the wording of the plaintiff's lease and not by surrounding circumstances, as other potential tenants would have to determine the extent of the restrictive covenants by a plain reading of the lease and not by extraneous events. At page 569 of the judgment, Lacourciere J. stated:

There is an obvious reason why the intention of the parties should be governed by the wording of the lease, and not by surrounding circumstances: other tenants, having actual or constructive notice of the lease, who contract with the landlord, must be able to determine, from a plain reading of the lease itself, what are the contractual relations affecting them insofar as restrictive covenants are concerned. They are not expected to examine the physical layout of the lessee's business or peruse past financial records, or negotiation history of the lease, to determine what constitutes the tenant's true business: they are entitled to rely on the description of the tenant's business adopted by the parties in the governing clause. In addition, the business carried out by Higgins was described as an "office supply and stationery" business on the store front. To rule otherwise would be most unfair to third parties such as Tamblyn or Supersave who in good faith established their business.

3. (1975) 5 O.R. (2d) 563. 
The court applied the doctrine of verba chartarum fortius accipiuntur contra proferentem i.e. that ambiguities contained within the clause must be construed against the party who is offering them. The learned Justice reasoned that if the parties had intended to confer on the plaintiff the exclusive right to sell all articles of smoking, the clause would have been worded differently and more explicitly, and cited the dictum referred to above of Fry L.J. in the Stuart v. Diplock Bros. case.

The court followed the principle established in Stop \& Shop Ltd. v. Independent Builders Ltd. ${ }^{4}$ In this case, it was held by Kingstone J. that the mere fact that there was an overlap in the goods sold by a grocery and meat business and a delicatessen store did not make the sale of similar articles sold in both businesses a breach of the covenant invoked. The business carried on by the grocery and meat store was substantially different and distinct from that of the delicatessen store, with competition being created by reason of the overlap of the similar goods sold by both, rather than that such overlap caused a breach of the exclusive rights covenant.

In the Stop \& Shop Ltd. case, Kingstone J. said:s

\begin{abstract}
I have to construe the words in this covenant as the parties have expressed them, and not as what they may have intended to say. The lessor covenants and agrees "not to lease to any person who will use the same for the purpose of carrying on a grocery or meat business." The covenant is, therefore, (1) not to lease to any person (2) who will use the same. (1) The Koury lease provides that no other business than a delicatessen business shall be carried on in the premises. Unless therefore the plaintiff can establish that the delicatessen business is substantially the carrying on of a grocery or meat business, there has been no breach so far as the letting is concerned. (2) Who will use the same. If there has been any user by the tenant, apart from the letting, which violates the plaintiff's contract, has the plaintiff any remedy against the landlord? Here the covenant does not say that no groceries or meats are to be sold, but merely that no other premises are to be let for the purpose of carrying on a grocery or meat business. It would seem to me, therefore, if the delicatessen business is not a carrying on of a grocery or meat business, the landlord is in no sense guilty of the breach complained of, regardless of what the tenant sells or displays in his store.
\end{abstract}

In all of these cases, it was held that the defendants could not be restrained simply because they sold certain lines similar to those sold by the respective plaintiffs.

The issues in the Stuart, Stop \& Shop Ltd. and $K \& L$ Higgins Ltd. cases all revolved around covenants against the carrying on of a certain type of business and not as against the sale of specified products. In each of the cases the alleged competitor was operating a well established separate type of business although certain lines of goods sold in the competing business were the same as those sold in the plaintiff's business, which the plaintiff sought to protect.

However, these cases were distinguished by Spence J. in the judgment of the Supreme Court of Canada in Russo v. Field. ${ }^{6}$ In this case, the owner of a small suburban shopping centre leased certain premises to the plaintiff Russo to carry on business therein as a hairdresser and beauty salon. The lease to the plaintiff recited the common intent of the defendant landlord and the plaintiff that the stores in the shopping centre should be noncompetitive and the landlord agreed that it would not permit any of the
4. [1933] 1 D.L.R. 727.
5. Id. at 731 .
6. [1973] S.C.R. 466. 
other stores in the shopping centre to carry on the business of a hairdresser and beauty salon. The landlord subsequently leased premises in the shopping centre to the defendant Field to conduct business as a manufacturer, retailer and servicer of wigs. In this lease, the landlord covenanted with the defendant Field not to permit other stores to carry on the "principal business of manufacturing and retailing wigs and servicing wigs".

The premises of the plaintiff and of the defendant Field were immediately adjoining in a small suburban shopping centre containing only ten stores, one of which was a supermarket. In all of the leases, with the exception of the lease to the defendant Field, the landlord had expressed its intent that the stores in the shopping centre were to be non-competitive.

The Supreme Court allowed the appeal from the Ontario Court of Appeals decision to overturn the trial judge's award in favour of the plaintiffs.

At page 486 of the judgment, Spence J. stresses that the circumstances of each case are important and stated:

It has been said that covenants such as those under consideration in this action are covenants in the restraint of trade and therefore must be construed restrictively. I am quite ready to recognize that as a general proposition of law and yet I am of the opinion that it must be considered in the light of each circumstance in each individual case.

The evidence showed that at the time the landlord leased the stores to the plaintiff and the defendant Field, the selling and servicing of wigs was an integral part of the hairdressing and beauty salon business. It was held that under the particular circumstances existing in this case, the leasing of the premises to the defendant Field and the carrying on of the business therein of a wiggery was a breach of the covenant in the plaintiff's lease.

Russo registered a notice of the lease in the Land Titles Office. The court held that the defendant Field had notice of the provisions of the lease to the plaintiff Russo, although the evidence showed that the defendant Field did not have actual knowledge of the terms of the Russo lease. The evidence of Field, which was accepted, was that she had not retained a solicitor nor conducted any searches in the Land Titles Office nor made any inquiries as to what protection other stores in the shopping centre, and particularly that of the plaintiff, enjoyed by virtue of the provisions of their leases. However, the Court held that the defendant Field had notice of the restrictive covenant in the plaintiff's lease by virtue of the registration thereof. Therefore, because the selling and servicing of wigs at the time the landlord leased the stores to the plaintiff and the defendant Field was recognized in the trade as an integral part of the hairdressing and beauty salon business, under the particular circumstances prevailing in this case, it was held that the defendant Field was operating a business that was in competition with the plaintiff's business contrary to the covenants in the plaintiff's lease.

Re Spike and Rocca Group Ltd.' is a decision of the Prince Edward Island Supreme Court in which the applicant, a tenant of a small shopping plaza consisting of approximately twelve stores, applied for an injunction to prohibit another tenant in the same shopping plaza from cutting ladies'

7. (1979) 107 D.L.R. (3d) 62. 
or girls' hair or advertising in the media the extension of his business to that of ladies' haircutting and styling. The applicant, Spike, operated a beauty salon. Rocca Group Ltd., the landlord of the shopping plaza, had covenanted with Spike that it would not lease any other premises in the shopping centre to a tenant "doing ladies' hairstyling and/or operating a uni-sex beauty salon". The respondent Muise operated a men's hairstyling and barber shop but had sought to extend his service to ladies' haircutting and styling and had advertised such services in the press. Spike brought an injunction to prohibit Muise from cutting ladies' or girls' hair, alleging that such action was in breach of the restrictive covenant of the landlord in Spike's lease.

McQuaid J., stated at page 64:

As I view the matter now before the Court, the issues go deeper than the simple issue of the right of injunction as between Spike and Muise. The increasing proliferation of shopping malls across the country is creating, I suggest, a new body of law, peculiar thereto. Included therein is the question of restrictive covenants in leases, and their mutual enforceability as between tenants by implication. The conditions and circumstances in which the common law has dealt with these and other questions in the past may well have altered sufficiently in this new context to require rethinking and extension. The law should not be an immutable monolith, but should be capable of adapting itself to changing times and circumstances. Only after this aspect of the matter has been explored, and a premise established, can the principal issue of the proposed injunction itself be looked to.

Although there was no direct privity of contract as between Spike and Muise, the Court held that, since each party was an individual tenant to a common landlord of the shopping centre and the clear intent of each lease was such that it created a community of interest as between tenants of parallel business operations in the shopping centre, an indirect privity of contract existed between the tenants. Consequently, each tenant had a direct interest in the carrying out of the terms of the lease by the other tenants.

Accordingly, it is submitted that if it is sufficiently clear from the respective leases of tenants in a shopping centre that a community of interest is created, and provided that the covenant in restraint of trade is lawful, then such covenants will be mutually and reciprocally enforceable as between landlord and tenant, as well as between tenants of the shopping centre.

Restrictive covenants in shopping centre leases are arguably covenants in restraint of trade, ${ }^{8}$ and all such covenants are prime facie void at common law. To be enforceable, a covenant in restraint of trade must be reasonable with reference both to the interests of the parties concerned and the public at large. Lord Macnaghten in Nordenfelt v. Maxim Nordenfelt Guns \& Ammunition Co.' stated at page 565 that:

The true view at the present time I think, is this: The public have an interst in every person's carrying on his trade freely: so has the individual. All interference with individual liberty of action in trading, and all restraints of trade themselves, if there is nothing more, are contrary to public policy, and therefore void. That is the general rule. But there are exceptions: restraints of trade and interference with individual liberty of action may be justified by the special circumstances of a particular case. It is a sufficient justification, and indeed it is the only justification, if the restriction is reasonable -

8. Russo v. Field [1973] S.C.R. 466.

9. [1894] A.C. 535. 
reasonable, that is, in reference to the interests of the parties concerned and reasonable in reference to the interests of the public, so framed and so guarded as to afford adequate protection to the party in whose favour it is imposed, while at the same time it is in no way injurious to the public. That, I think, is the fair result of all the authorities.

The onus of establishing the reasonableness of a restraint rests upon the party who would support it. ${ }^{10}$

It is submitted that restrictive covenants in shopping centre leases must be construed in the light of each circumstance in each individual case. The reciprocal restrictive covenants between the landlord and tenant of the shopping centre constitute a part of the consideration of the contract. One of the inducements to a tenant to lease space in a shopping centre is the security of knowing either that competition from the operation of a competing store by another tenant in the shopping centre is limited or eliminated entirely, or, at least, that competition in certain lines of merchandise from a competing store will be limited or eliminated. It is further submitted that, depending upon the circumstances, our courts may not construe restrictive covenants in shopping centre leases as strictly as they would construe restrictive covenants in other forms of contract. For example, in Spike's case, the court found that there was a common link of consideration in that a community of interest between Spike and Muise was created, by virtue of which Spike had an action against Muise even though there was no direct privity of contract between these tenants.

Similarily, at page 487 of Russo's " case, Spence J. stated that:

I am therefore of the opinion that the disposition as a matter of public policy to restrictively construe covenants which may be said to be in restraint of trade has but little importance in the consideration of the covenants in the particular case.

Laskin J.A. (as he then was) in considering the lawfulness of restrictive covenants in their relation to a shopping centre lease restated the competing considerations to be taken into account: $:^{12}$

The policy of favouring competition and alienability of property suggests a strict construction of agreements that would flout it. Accordingly, the relative freedom to contract for a limitation of competition and of the use of property should be reflected in precise language to ensure that the limitation is fully spelled out. On the other hand, it is also arguable that alienability of property is promoted by protecting its commercial use by a covenant against competition which should, accordingly, be benevolently construed. Moreover, one of the attractions of a shopping centre for operators of businesses is the assurance of protection of their enterprises through an orderly scheme of development; and an element of the scheme may be provision of some cover against competition as among those who agree to establish businesses in the centre . . . I do not think, however, that the element of mutuality should be taken to excuse a failure to provide against any degree of competition, unless this is clearly the sense of the terms in which the protection is couched.

\section{ENFORCEABILITY}

The New Brunswick Court of Appeal, in F.W. Woolworth Co. Limited v. Hudson's Bay Company, Burnac Leaseholds Limited and Zeller's Inc. ${ }^{13}$ considered the enforceability of restrictive covenants. Burnac developed a

10. McEllistrim v. Ballymacelligott Cooperative Agricultural \& Dairy Society Ltd. [1919] A.C. 548.

11. Supra n. 6.

12. (1970) 12 D.L.R. (3d) 665 at 685-6.

13. (1985) 61 N.B.R. (2d) 407. 
regional shopping centre near Bathurst, New Brunswick in which it leased premises to Hudson's Bay to operate a department store under its own name. Burnac also leased premises to Woolworth to operate a "Woolco" junior department store in the same centre. These tenants were to be two of the three major tenants in the shopping centre. Woolworth stressed from the outset of negotiations with Burnac that it did not want a 'Zeller's"' store in the shopping centre. The Hudson's Bay lease, at the insistence of the tenant, contained provisions allowing it to assign its lease to a subsidiary.

Article 31 of the Woolworth lease contained a restrictive covenant reading as follows:

Restrictive Covenant

Art. 31. So long as F.W. Woolworth Co. Limited leases, uses, or occupies any space in the area described in Schedule " $A$ " hereof as Entire Premises, the Landlord covenants that notwithstanding the amendment, cancellation, termination or expiration of the herein lease: (a) no covenant or agreement not specified in Schedule " $B$ " hereof made by the Landlord with any other person or corporation restricting the use or occupancy of all or part of said Entire Premises or Right-of-Way Premises shall be of any force or effect against F.W. Woolworth Co. Limited, (b) no building or structure shall be erected or maintained on any part of the Entire Premises or Right-of-Way Premises except in the area designated Building Area or Future Building Area on the drawing attached to Schedule "A" hereof, (c) except as permitted by Art. 27 (Section II-Other Tenants), no building, structure, or other space in said Entire Premises or Right-of-Way Premises having a ground floor area in excess of 10,000 square feet shall be leased to or used or occupied by a person or corporation unless said lease, use or occupancy is specifically consented to in writing by the Tenant, (d) except as permitted by Art. 27 (Section II-Other Tenants) and except for a Marks and Spencer Store not in excess of 10,000 square feet of gross floor area, no other space in said Entire Premises or Right-of-Way Premises shall be used or occupied as, or in connection with, a store commonly known as a variety store, junior department store, department store, or a catalogue or catalogue distribution store, and (e) no other space in said Entire Premises or Right-of-Way Premises shall be used or occupied as or in connection with a store, shop or service facility commonly known as a T.B.A. or an auto accessory store, except that the space designated "Gas Bar Future Building Area" shown on the aforesaid drawing may be used only for the sale of gasoline, oil, solvents, cleaners and other motor additives and shall not be used or occupied for any other purpose or purposes unless said use or occupancy is specifically consented to in writing by the Tenant prior to such use or occupancy.

Article $\mathbf{2 7}$ of the Woolworth lease provided that Woolworth specifically consented to the lease, use and occupancy by specific tenants of space in the shopping centre, one of which was Hudson's Bay, but none of which was using or occupying space, or was entitled to use or occupy space as a junior department store.

The "Woolco" store was constructed and opened approximately four months before the Hudson's Bay store opened for business. The department store operated by Hudson's Bay did not prosper and it assigned its lease to its subsidiary, Zeller's, in August, 1981 so that Zeller's could operate a junior department store in the shopping centre. Woolworth immediately commenced an action for an injunction restraining the Hudson's Bay, Burnac and Zeller's from using the Hudson's Bay space in the shopping centre as a junior department store, inter alia.

The evidence clearly disclosed that Woolco and Zeller's were major competitors and both operated junior department stores, as opposed to the type of department store commonly referred to in the shopping centre industry as a "major department store" operated by Hudson's Bay. Woolworth contended that Article 27 of its lease, as well as the provisions 
of the Hudson's Bay lease, contemplated the use of the Hudson's Bay space as a department store. Furthermore, Article 31(c) required Woolworth's consent to the lease, use or occupancy of space exceeding ten thousand square feet to or by any other tenant. Article 27 gave that consent in advance for four stores, including the Hudson's Bay space for use as a department store, but not for use as a junior department store. Woolworth's position was that Article 31(d) together with the previous provisions prohibited Burnac from permitting the operation of a Zeller's store in the shopping centre unless Woolworth first consented, which consent had not been given.

On the facts, the Court found that the Woolworth lease prohibited the use of Hudson's Bay space by Zeller's as a junior department store. The issue than arose whether this prohibition was one in restraint of trade and, if so, whether the restriction could be justified as being reasonable, both in the interests of the parties and the public. Initially, the court considered whether the restriction in the Woolworth lease constituted a restraint of trade. As a starting point, Hoyt J.A. cited the definition of a contract in restraint of trade of Lord Wilberforce at page 332-3 of his judgment in Esso Petroleum Co. Ltd. v. Harper's Garage (Stourport) Ltd.: $:^{14}$

\begin{abstract}
How, then, can such contracts [in restraint of trade] be defined or at least identified? No exhaustive test can be stated - probably no precise non-exhaustive test. But the development of the law does seem to show that judges have been able to dispense from the necessity of justification under a public policy test of reasonableness such contracts or provisions of contracts as, under contemporary conditions, may be found to have passed into the accepted and normal currency of commercial or contractual or conveyancing relations. That such contracts have done so may be taken to show with at least strong prima facie force that, moulded under the pressures of negotiation, competition and public opinion, they have assumed a form which satisfies the test of public policy as understood by the courts at the time, or, regarding the matter from the point of view of the trade, that the trade in question has assumed such a form that for its health or expansion it requires a degree of regulation. Absolute exemption for restriction or regulation is never obtained: circumstances, social or economic, may have altered, since they obtained acceptance, in such a way as to call for a fresh examination: there may be some exorbitance or special feature in the individual contract which takes it out of the accepted category: but the court must be persuaded of this before it calls upon the relevant party to justify a contract of this kind.
\end{abstract}

Some such limitations upon the meaning in legal practice of "restraints of trade" must surely have been present to the minds of Lord Macnaghten and Lord Parker. They cannot have meant to say that any contract which in whatever way restricts a man's liberty to trade was (either historically under the common law, or at the time of which they were speaking) prima facie unenforceable and must be shown to be reasonable. They must have been well aware that areas existed, and always had existed, in which limitations of this liberty were not only defensible, but were not seriously open to the charge of restraining trade. Their language, they would surely have said, must be interpreted in relation to commercial practice and common sense.

In Esso the House of Lords drew a fundamental distinction between the situation that exists on the one hand between the trader who gives up some of his present freedom for some advantage from the party claiming the benefit of the restrictive covenant, and, on the other hand, a person who wishes to become a trader and to do so obtains trading premises on terms which subject him to a restraint. In the former instance, the person accepts restraints on property that he already owns, whereas in the latter, the person has lost no right so he may be subjected to restraint. Only in the 
former instance is the contract one in restraint of trade. After considering both the Russo and Spike cases, the Court held that the restriction in the Woolworth lease did not constitute a restraint of trade.

However, Hoyt J.A. found even that were the restriction to have constituted a restraint of trade, the covenant could be justified as it met the test of reasonableness in the circumstances, in that it was reasonable in the interests of both the parties and the public; nor was it contrary to the public interest and went no further than was necessary to afford adequate protection to Woolworth.

One of the defences raised by Hudson's Bay, Burnac and Zeller's was that the restrictive covenants were personal covenants between Woolworth and Burnac and did not run with the land. In law, a restrictive covenant is deemed to run with the land only in the following two circumstances: ${ }^{15}$

(a) Where the covenant, whether or not expressly made binding upon the successors and assigns of the grantee to whom it is initially conveyed, is expressly stated to run for the benefit of described lands of the covenantee; or, even if failing that,

(b) The land against which the covenant is to run and the land for the benefit of which the covenant is to run are both part of a common building scheme, all parts of which are subject, if not totally then at least substantially, to the same restrictions.

At common law, both the burden and the benefit of a covenant which touches or concerns land and is not merely personal or collateral will run with the land as between parties to such an agreement. However, equity permits a considerably wider range of persons to sue and be sued; there is no need for privity of contract or estate between the plaintiff and the defendant; the burden entered into by the parties may pass in equity and an underlessee or other occupier may be bound by such a covenant, provided certain conditions are present..$^{16}$

There are four requirements that must be met before a restrictive covenant in a building scheme can be upheld, namely:

(i) there must have been a common vendor under whom the various owners derive title;

(ii) before the lands are sold there was a scheme relating to a defined area for sale in lots containing restrictions which were to be imposed on all the lots and which, though varying in details as to particular lots, were consistent only with some general development;

(iii) the restrictions were intended by the vendor to be and were for the benefit of all the lots, whether or not they were also intended to be and were for the benefit of other land retained by the vendor; and

(iv) that the original purchasers bought on the understanding that the restrictions were to enure for the benefit of the other lots included in the general scheme."

It is not important that the arrangement is technically labelled as a building scheme. Therefore, the courts will not look to the form but rather to the substance of the arrangement and, provided the underlying system or plan possesses the characteristic attributes of a building scheme as set out above, it will be construed as such.

15. Friesen v. Valleyview Estates Ltd. (1977) 18 N.B.R. (2d) 1 at 5.

16. 16 Halsbury's Laws (4th) p. 904-ff.

17. Id. at 912-ff. 
The concept of a shopping mall has been regarded as a scheme analogous to a building scheme to which the principles of a building scheme shall apply. The rationale for injecting into the shopping mall concept the implied principle of a building scheme is that prospective tenants are attracted to a shopping centre because of the internal non-competitive aspects and the assurance of protection through the orderly scheme of development and the community of interests, as noted by Spence $J$. in the Russo case referred to above.

Scharf v. Mac's Milk $L t d .^{18}$ is an early authority for the principle that a shopping mall is analogous to a building scheme. In Scharf's case, a shopping centre was constructed with the individual stores intended for sale to the several "tenants" rather than for lease as is current practice. However, there was no "building scheme" registered. In view of the mutual and reciprocal benefit being extended to individual purchasers of the separate stores constituting the shopping centre, the court imputed the existence of a building scheme to the shopping centre.

In Spike, McQuaid J. held that as between purchasers and lessees the only difference is that purchasers hold an estate in freehold whereas lessees hold an estate for a term of years. ${ }^{19}$ The Court applied Scharf's case and found that leasehold interests can be the subject of a building scheme.

In the Woolworth case, Hoyt J.A. found that the shopping centre developed by Burnac was a scheme analogous to a building scheme and that trade carried on by Zeller's would be competitive with that of "Woolco" and would have a prejudicial effect upon Woolworth.

Even though a building scheme constitutes a local law for the area over which it extends, the parties thereto must have notice of the scheme. In the case of a shopping centre, the various tenants and their successors must have notice of the building scheme to achieve the practical effect of rendering each tenant and its successors subject to the restrictions imposed by the building scheme. Notice can be actual notice, whether by virtue of registration in the Land Titles Office pursuant to statute, or otherwise, or may be constructive notice. In the Russo case, there was registration in the Land titles Office pursuant to the Ontario Land Titles Act. However, in Spike's case, neither of the leases was registered, and it was argued that the respondent Muise would have no notice of the "exclusive" covenants entered into between Spike and the landlord pursuant to which the landlord covenanted that it would not lease any other premises in the shopping centre to a tenant doing ladies' hairstyling and/or operating a uni-sex beauty salon. Dealing with the issue of whether there was constructive notice or not by Muise, McQuaid J. at page 67 held: $:^{20}$

I cannot accept this argument. I think that with the passing of the years and the rapid growth of shopping centres, the internal non-competitive aspect, excluding, of course, those large sprawling developments which are essentially commercial districts in themselves, is sufficiently well-known and generally accepted as to be notorious, and common knowledge among all prospective tenants. That, as has been noted above, is one of their attractive features insofar as tenants are concerned, and one of the reasons why they seek to become tenants.

18. [1965] 2O.R. 640.

19. Supra n. 7.

20. Id. 
I would be of the opinion, and so hold, that, even though Muise might have been unaware at the time he entered into his lease of the contents of the lease then being negotiated with Spike, or that there was even such a lease being negotiated, as a reasonable businessman he could and should have anticipated that in view of the fact that his own lease contained a restrictive covenant, to his benefit, any other potential lease covering women's hairstyling (from which he was precluded) would have a parallel covenant for the benefit of such lessee. The notice of what was in his own lease was constructive notice, in the circumstances of what he might to find in another lease of the same nature. The other side of the coin is that Spike, by examining his lease, would be aware of what he might expect to find in the Muise lease, were it available to him.

It is submitted that prospective tenants in shopping centres failing to inquire about the existence and terms of restrictive covenants entered into between the landlord and other tenants of the shopping centre, may do so at their own peril. Indeed, in certain circumstances, a tenant may be deemed to have had constructive notice of the existence of an "exclusive right" if it deliberately abstains from inquiry in an attempt to avoid actual notice. The foregoing will be considered in the light of the circumstances in each individual case.

On the facts of the Woolworth case, the court held that Hudson's Bay had actual notice that Woolworth did not want a Zeller's store in the shopping centre, both by virtue of the registration of the Woolworth lease prior to finalization of the Hudson's Bay lease, and because of the covenants in the Woolworth and Hudson's Bay leases. Accordingly, the Court of Appeal held that there was a breach of the restrictive covenant in the Woolworth lease when the Hudson's Bay assigned its lease to Zeller's without the consent of Woolworth; that Hudson's Bay had actual notice of the restrictive covenant and granted an injunction to Woolworth.

In addition to being unenforceable at common law if it is unreasonable or contrary to the public interest, a restrictive covenant in restraint of trade is potentially unenforceable if it infringes the provisions of the Combines Investigation Act, ${ }^{21}$ as amended, which makes it an offence:

32(1)(c) To prevent, or lessen, unduly, competition in the production, manufacture, purchase, barter, sale, storage, rental, transportation or supply of a product, or in the price of insurance upon persons or property....

The argument could be made that a restrictive covenant in a lease would unduly lessen competition. However, the courts have confined this offence to acts which affect the marketplace as a whole. Unless the restrictive covenant in a shopping centre lease was such that there remained no market for commercial real estate in the area, it would not infringe this provision of the Act. For a more detailed discussion on how the Combines Investigation Act affects shopping centre leases, see: Roberts Anticombine and Antitrust at chapter 19 and the article entitled "The Amended Combines Investigation Act and its Application to Shopping Centres" by R.S. Carswell and R.J. Balfour. ${ }^{22}$

At pages 419 and 420 of their article ${ }^{23}$ Haber and Messinger state that:

... in light of the amendments made to the Combines Investigation Act and on the basis of guidelines that have been developed for use in the United States, drafters of shopping centre leases in Canada would be well advised to consider the following when preparing a

21. R.S.C. (1970), c-23.

22. (1980) and Shopping Centre Leases, supra n. 1 at 173.

23. Supra n. 1 . 
lease because each describes an act or course of conduct which may well be held to be prohibited and in violation of the recent legislation:

(a) no lease should contain provisions against discounting;

(b) there should be no price controls and wording about medium priced or high priced stores in use clauses;

(c) if exclusives are granted, the landlord should also require an indemnification clause providing that the exclusive clause is in the lease at the request of the tenant;

(d) radius restrictions, within reason, are still not violations but this may be an area where challenges may arise;

(e) all leases should eliminate any reference to advertising controls outside the shopping centre;

(f) no rights of approval over other tenants should be included in favour of one tenant or a group of tenants.

At page 419, the authors recommend that to prevent the entire lease from being declared invalid and unenforceable, the parties should include a severability clause to the effect that the lease remains valid despite the invalidity or unenforceability of one or more of the lease provisions.

\section{CONCLUSION}

An interesting question, and one yet undecided by our courts, is whether exclusive rights clauses will be upheld in leases in shopping centres which are, in the words of McQuaid J., "those large sprawling developments which are essentially commercial districts in themselves". ${ }^{24}$ The Learned Justice seems to imply that the large shopping centres may lack that internal non-competitive aspect which is so characteristic of the neighbourhood strip and the smaller suburban shopping centre. If one accepts that the larger, regional shopping centre lacks this internal noncompetitive aspect, then it might be argued that tenants of regional shopping centres cannot be expected to have notice of, and need not inquire into, exclusive rights covenants entered into between the landlord and other tenants of the shopping centre. However it is submitted that, irrespective of the size of the shopping centre, the same principles regarding notice and enforcement of these covenants should and would apply, taking into account the particular circumstances of each case. Certainly, as more cases dealing with this topic are decided by our courts, the principles governing restrictive covenants in shopping centre leases are going to be carefully examined and may even be rethought and extended as our courts adapt to changing times and circumstances. 